\title{
Tyrosine Kinase Inhibitors in the Treatment of Choroidal Metastases from Non-Small-Cell Lung Cancer: A Case Report and Review of Literature
}

\author{
Akshay Gopinathan Nair ${ }^{a-d}$ Haresh T. Asnani ${ }^{a, c}$ Vinod C. Mehta ${ }^{c}$ \\ Siddharth V. Mehtac Rima S. Pathak ${ }^{\mathrm{e}} \mathrm{g}$ Amit H. Palkard Indumati Gopinathan ${ }^{\mathrm{f}}$ \\ ${ }^{\mathrm{a}}$ Advanced Eye Hospital and Institute, ${ }^{\mathrm{b}}$ Aditya Jyot Eye Hospital, ${ }^{\mathrm{C}}$ Mehta Eye Clinic Pvt. Ltd., ${ }^{\mathrm{d}}$ Lokmanya Tilak \\ Municipal Medical College and Hospital, ${ }^{\mathrm{T}}$ Tata Memorial Cancer Hospital, and ${ }^{\mathrm{f} C l i n i c o-P a t h}$ Labs, Mumbai, India; \\ ${ }^{g}$ British Columbia Cancer Agency, Abbotsford, B.C., Canada
}

\section{Key Words}

Choroidal · Metastases · Lung cancer · Non-small-cell lung cancer · Erlotinib - Epidermal growth factor receptor .

Tyrosine kinase inhibitors · Targeted therapy

\begin{abstract}
Background: Choroidal metastases being the sole presenting feature of lung cancer is rare. Erlotinib, a tyrosine kinase inhibitor (TKI), is used in the treatment of lung adenocarcinoma where tumor cells exhibit epidermal growth factor receptor (EGFR) mutations. We report a case of metastatic nonsmall-cell lung cancer (NSCLC) with choroidal metastasis, which was the sole presenting feature and which responded to erlotinib. Methods: We performed a retrospective case review. Case: A 78-year-old man presented with a choroidal mass which was found to be the presenting feature of metastatic NSCLC. Our patient, a nonsmoker, had disseminated bony metastases, and therefore was advised to undergo palliative chemotherapy, which he refused. He was therefore instituted on oral erlotinib. Results: Tumor cells expressing EGFR mutations are known to be susceptible to TKls. Even though the tumor in our case showed no mutation, i.e. was classified as 'wild-type', our patient showed a dramatic response to erlotinib. At 1 year, the choroidal lesion had regressed and visual acuity had recovered. Conclusions: TKls may be beneficial in patients with choroidal metastases from
\end{abstract}

\section{KARGER}

(c) 2016 S. Karger AG, Basel

E-Mail karger@karger.com

www.karger.com/oop
NSCLC, especially those in which an EGFR mutation is noted. Even in the absence of such mutations, choroidal metastases may show a favorable effect in response to TKIs, such as erlotinib.

(c) 2016 S. Karger AG, Basel

\section{Introduction}

Lung cancer is the leading cause of cancer deaths in the world. Non-small-cell lung cancer (NSCLC) accounts for the majority of lung cancer cases, nearly half of which are diagnosed at an advanced stage, adenocarcinoma being the most common histologic subtype $[1,2]$. Choroidal metastasis is the most common intraocular tumor in adults, particularly affecting the posterior pole [3]. The reported prevalence of ocular metastasis arising from the lung ranges between 9 and 23\% [4]. Over the years, the spectrum of treatment for choroidal metastasis has shifted from enucleation, radiotherapy and conventional chemotherapy to intravitreal injections and targeted therapy. In this communication, we report an unusual case of unilateral choroidal metastasis arising from a NSCLC of the adenocarcinoma subtype, which responded to oral erlotinib, an oral tyrosine kinase inhibitor (TKI). We also review the available literature on the treatment of choroidal metastases from primary tumors in the lung using TKIs.

Akshay Gopinathan Nair, DNB 
Fig. 1. a Fundus photograph at presentation showed a well-defined yellowish-colored circular subretinal lesion along the superior arcade. Also note the small, discrete, pin-point yellowish 'satellite lesions' between the optic disc and the macula. b Posttreatment fundus photograph of the left eye showed scarring and exudation. The lesion was however flat with no subretinal fluid.
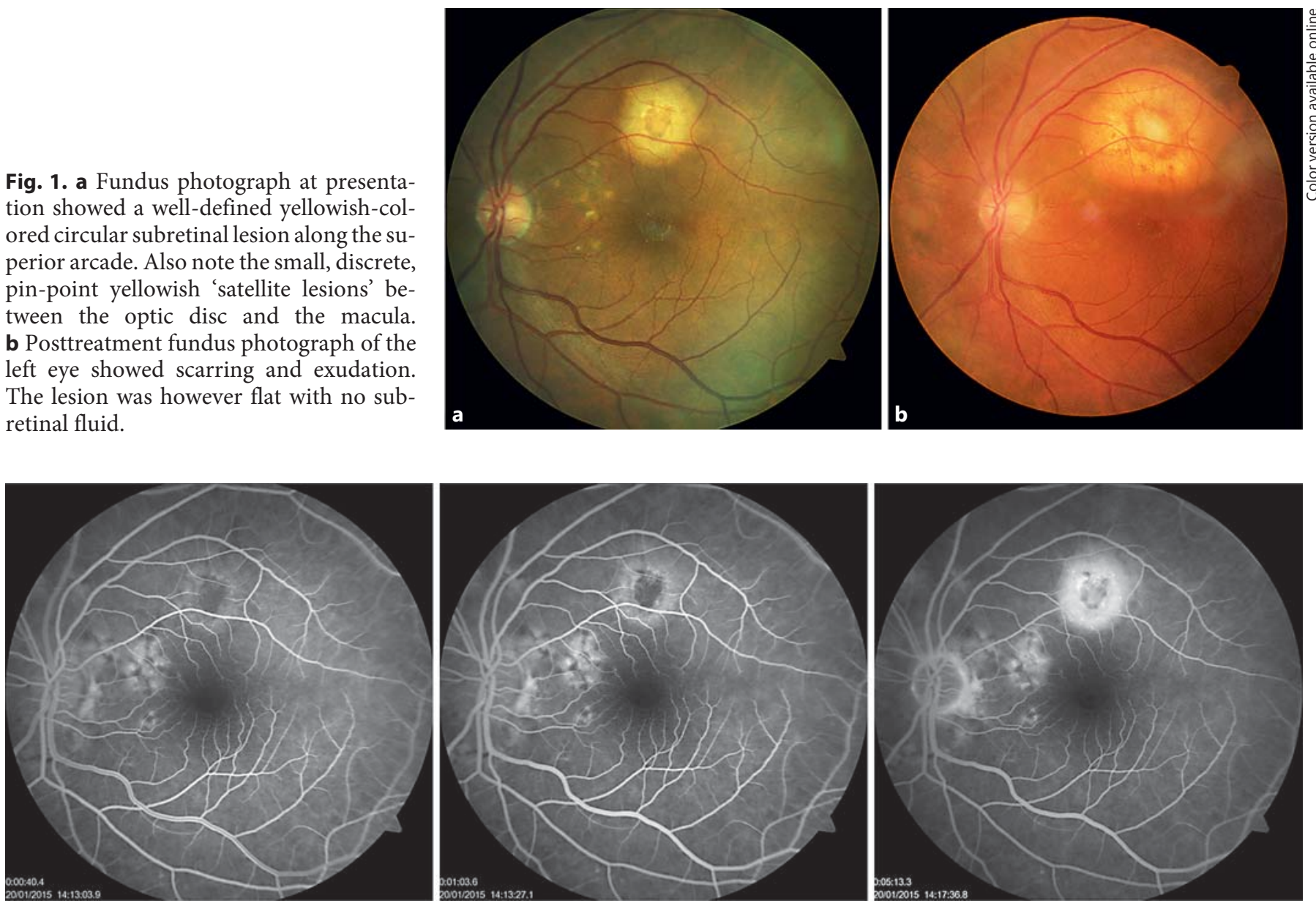

Fig. 2. Fundus fluorescein angiography showed central hypofluorescence with a ring of peripheral hyperfluorescence in the early phase that gradually increased in intensity and size in the late phase.

\section{Case Report}

A 78-year-old male patient presented with a 3-month history of gradually progressive diminution of vision in the left eye. He had no associated complaints of redness, watering, pain, or discharge. On ocular examination, best corrected visual acuity in the right eye was 20/25, N6 and 20/60, N10 in the left eye. Anterior segment evaluation was unremarkable in both eyes except for pseudophakia. Intraocular pressure in both eyes was normal. Dilated fundus evaluation of the right eye was normal, the left eye however showed a well-defined yellowish-colored circular subretinal lesion along the superior arcade (fig. 1a). The mass had feathery margins and measured approximately two disc diameters in size. The vitreous cavity was clear with no signs of inflammation. Small, discrete, pinpoint yellowish 'satellite lesions' were also noted between the optic disc and the macula. In the early phase, fluorescein angiography showed central hypofluorescence with a ring of peripheral hyperfluorescence that increased in intensity and size in the late phase (fig. 2). Optical coherence tomography (OCT) of the left eye through the macula showed neurosensory detachment with the presence of subretinal fluid (fig. 3a). Scans through the lesion showed an irregular, dome-shaped subretinal lesion (fig. 4a). The retinochoroidal junction was indistinct and the underlying choroid had assumed an uneven, hump-shaped configuration. Choroiditis, choroidal granuloma, and choroidal metastasis were the differential diagnoses that were considered. Hematological investigations revealed no infective disease pathology, and an exhaustive panel of serological investigations gave no results suggestive of any autoimmune disease process. Apart from a long-standing history of systemic hypertension and ischemic heart disease, the patient had no other systemic complaints.

A 7-day course of oral prednisolone at a dose of $1 \mathrm{mg} / \mathrm{kg}$ showed no change in the size of the lesion or in vision. At this point, with a working diagnosis of choroidal metastases arising from an occult primary, computed tomography-positron emission tomography (CT-PET) was performed, which showed a metabolically active lesion in the right hilar region measuring $3.5 \times 3.0 \mathrm{~cm}$, metabolically active mediastinal and tracheobronchial lymph nodes, and multiple lesions in the vertebrae. The findings corroborated the CT images, which showed a possible primary lesion to be a mass arising 

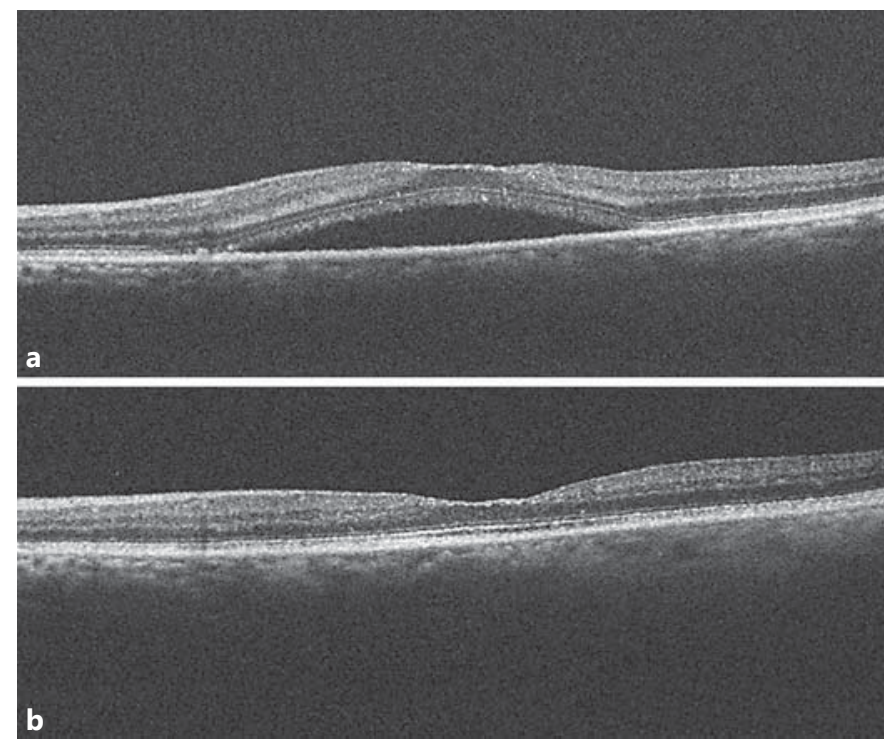

Fig. 3. a Pretreatment OCT of the left eye through the macula showed neurosensory detachment with the presence of subretinal fluid. b Posttreatment OCT of the left eye showed a normal foveal contour with no subretinal fluid.

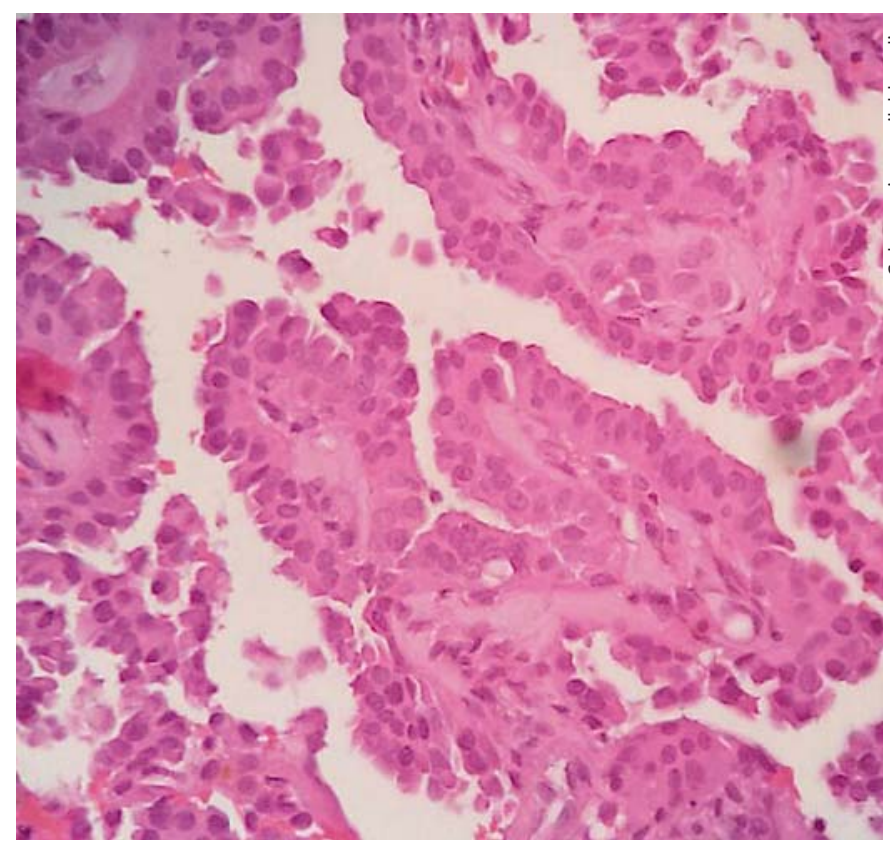

Fig. 5. Photomicrograph showing clusters of malignant cells with hyperchromatic nuclei and increased nuclear-cytoplasmic ratio in a papillary configuration. Hematoxylin-eosin. $\times 40$.
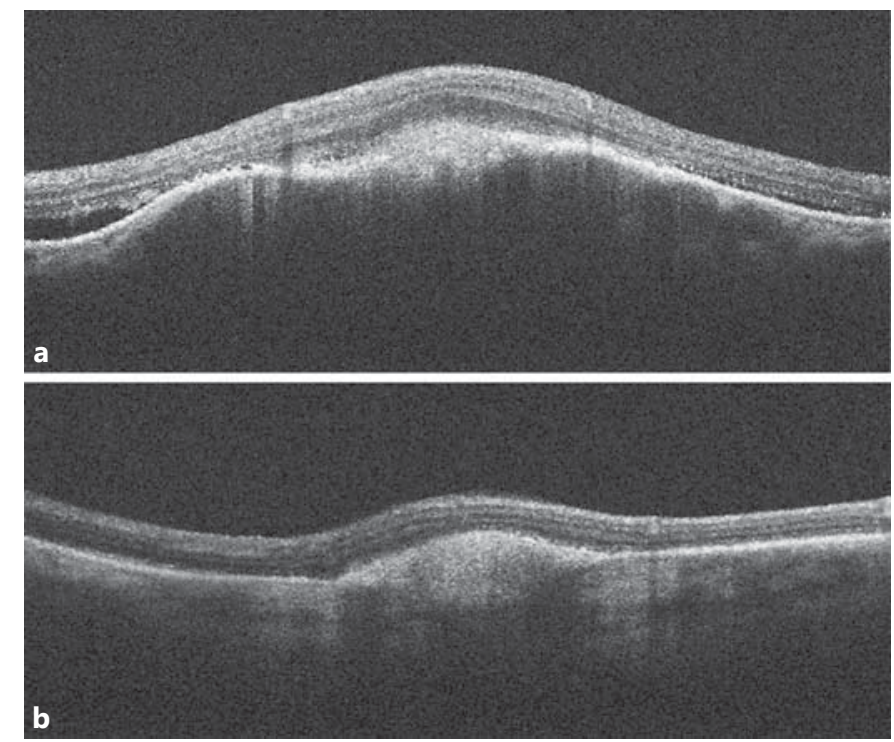

Fig. 4. a At presentation, OCT scan passing through the lesion in the left eye showed an irregular, dome-shaped subretinal lesion. The underlying choroid had an uneven, hump-shaped configuration. b Posttreatment OCT showed dramatic resolution with residual scarring and exudation.

in the right lung along with lytic bony lesions. A CT-guided biopsy was performed and on examination, it was found to be an adenocarcinoma with papillary configuration (fig. 5). Therefore, a final diagnosis of American Joint Committee on Cancer stage IV (T2a $\mathrm{N} 2 \mathrm{M} 1 \mathrm{~b}$ ) papillary adenocarcinoma of the lung with choroidal and bone metastases was arrived at. As per standard protocol, the tumor cells were tested (TaqMan probe-based endpoint genotyping mutation analysis by real-time polymerase chain reaction on the LightCycler 480 II; Roche Diagnostics, Risch-Rotkreuz, Switzerland) to detect EGFR mutations. No mutations were found on exons 18, 19, 20, and 21, therefore the EGFR was classified as 'wild-type'.

Palliative chemotherapy consisting of cisplatin and docetaxel was advised, with the option of palliative radiation also being discussed. However, the patient declined any form of intravenous chemotherapy or radiation. He was therefore prescribed oral erlotinib, $150 \mathrm{mg}$ daily. At 6-month follow-up the size of the choroidal tumor had decreased (fig. 1b), and OCT showed dramatic resolution of the choroidal mass with resorption of subretinal fluid (fig. 3b, 4b). The patient's vision had improved to $20 / 25$ in the left eye. At the last follow-up at 1 year, PET scans showed a good response at other sites of metastases; the patient was on oral erlotinib and had no new metastatic lesions or recurrence of the choroidal lesion.

\section{Discussion}

The treatment of choroidal metastases depends on many factors such as systemic status, laterality, presence of subretinal fluid, size, and number of tumors [5]. Tak- 
ing all factors into consideration, our patient was advised to undergo palliative radiation and systemic chemotherapy consisting of platinum doublets. He however refused radiation and any form of intravenous medications. $\mathrm{He}$ was then counselled further and prescribed oral erlotinib $150 \mathrm{mg}$. Erlotinib, a TKI, received FDA approval in cases of NSCLC as first-line treatment for patients with an EGFR mutation and as second-line treatment in advanced NSCLC if there is a relapse or disease progression after the first-line platinum-based combination treatment [5].

The EGFR protein itself is a transmembrane glycoprotein consisting of an extracellular ligand-binding domain, a transmembrane domain as well as an intracellular tyrosine kinase domain [6]. EGFR plays an important role in cancer cell proliferation, angiogenic growth factor production, and cancer cell invasion [7]. Some NSCLCs express EGFR and many tumors have EGFR mutations or gene amplifications. In patients in whom tumor cells have EGFR mutations, the growth of the tumor cells is nearly completely dependent on this EGFR signaling pathway. Hence, any disruption of this pathway causes regression of the tumor [8]. TKIs bind to the intracellular tyrosine kinase catalytic domain and block receptor autophosphorylation and downstream the signal. This leads to a cascade of events that finally lead to tumor growth arrest [9]. Therefore, the presence of these mutations indicates high sensitivity to a group of drugs known as TKIs. The advantage of such targeted therapy over conventional chemotherapy is more specificity towards tumor cells, a broader therapeutic window, and significantly less toxicity. Erlotinib has a relatively good safety profile, with only dose-dependent reversible side effects such as diarrhea and acneiform rashes [7].

Prior to the commencement of TKI therapy, it is required to screen for EGFR mutation in all NSCLCs on immunohistochemistry, fluorescence in situ hybridization, or mutational analysis [10]. The presence of EGFR mutations in adenocarcinoma is a predictor of responsiveness of the tumor to EGFR-TKIs [11, 12]. The most commonly detected mutations are deletions in exon 19, point mutation in exon 21 or insertions in exon 20. Cases that are mutation-negative are designated as 'wild-type' NSCLC [12].

There have been few reports documenting the response of choroidal metastases to erlotinib (table 1) [5, 7, 8, 13-17]. However, of the cases reported in the literature, only in three reports were the patients actually screened for genetic anomalies related to EGFR [7, 15, 17]. Of those, 2 patients were found to have aberrations with exon 19 and 1 with exon 21 . None of the previously reported cases were found to have no mutation, i.e. to be 'wild-type'. Among the TKIs, erlotinib was used more often than gefitinib. Most cases showed resolution of the choroidal tumor upon initiation of oral TKI therapy. However, 2 cases stand out. The first report is by Chen et al. [7], who reported the case of a 68-year-old female with metastatic papillary carcinoma of the lung with choroidal metastasis. Testing for EGFR mutations revealed a mutation at L861Q on exon 21. Oral erlotinib provoked a dramatic response with an improvement in tumor size and vision. However, after 7 months of treatment the choroidal lesion had increased in size, and subretinal fluid was noted which caused a drop in vision, necessitating a change in the treatment regimen [7]. The other case of interest is a 73-year-old male whose metastatic NSCLC was treated with systemic chemotherapy that included oral erlotinib [16]. The choroidal lesions worsened while he was on oral erlotinib, following which the lesions showed improvement on treatment with intravitreal bevacizumab; they remained stable for 4 months. No details on EGFR mutation screening are available for the second case. While EGFR mutations usually indicate a possible beneficial response to TKIs, here we have two different cases: one with an EGFR mutation that initially improved and then worsened, and the other, presumed to be wildtype, showing no beneficial response to erlotinib. Our case is different from both as despite having no detectable mutation, i.e. being wild-type, a dramatic response in tumor size was noted. This throws up more questions: Is there more to TKIs than merely EGFR blockage? Are there other factors at play [18]?

It is generally accepted that even in wild-type NSCLCs, TKIs - when used as second line drugs - demonstrate similar response rates, progression-free survivals, and median overall survivals as conventional chemotherapy agents [19-21]. While there is evidence to back the treatment of mutation-positive NSCLCs with TKIs as firstline therapy [22], conventional chemotherapy has been reported to be more effective than TKIs in mutation-negative patients [23]. First-line chemotherapy for NSCLC is usually cisplatin-based and can have significant adverse reactions. Conventional chemotherapy interferes with cell division and does not discriminate sufficiently between rapidly dividing tumor cells and normally dividing noncancerous cells. Therefore, toxic adverse effects like bone marrow suppression, nephrotoxicity, and hepatotoxicity are common. In comparison to this, targeted biologic agents like TKIs aim at disrupting specific molecular pathways that are involved in tumor growth, prolifera- 
Table 1. Summary of the cases of choroidal metastases from NSCLC in the literature treated with EGFR-TKIs

\begin{tabular}{|c|c|c|c|c|c|c|c|c|c|c|c|}
\hline Reference & $\begin{array}{l}\text { Age/ } \\
\text { sex }\end{array}$ & $\begin{array}{l}\text { Lung cancer } \\
\text { subtype }\end{array}$ & $\begin{array}{l}\text { Initial } \\
\text { vision }\end{array}$ & $\begin{array}{l}\text { Other } \\
\text { sites of } \\
\text { metastases }\end{array}$ & $\begin{array}{l}\text { EGFR } \\
\text { status }\end{array}$ & $\begin{array}{l}\text { Other } \\
\text { concurrent } \\
\text { chemotherapy }\end{array}$ & $\begin{array}{l}\text { EGFR-TKI } \\
\text { used }\end{array}$ & $\begin{array}{l}\text { Other } \\
\text { intraocular } \\
\text { treatment for } \\
\text { choroidal } \\
\text { metastasis }\end{array}$ & Outcome & $\begin{array}{l}\text { Final } \\
\text { vision after } \\
\text { treatment } \\
\text { with EGFR- } \\
\text { TKI }\end{array}$ & $\begin{array}{l}\text { FU } \\
\text { period }\end{array}$ \\
\hline $\begin{array}{l}\text { Kim et al. } \\
{[13], 2009}\end{array}$ & $57 / \mathrm{F}$ & $\begin{array}{l}\text { NSCLC - } \\
\text { adenocarcinoma }\end{array}$ & $20 / 200$ & $\begin{array}{l}\text { yes; } \\
\text { sites NS }\end{array}$ & NS & $\begin{array}{l}\text { yes; } \\
\text { docetaxel } \\
+ \text { cisplatin }\end{array}$ & erlotinib & $\begin{array}{l}\text { intravitreal } \\
\text { bevacizumab }\end{array}$ & $\begin{array}{l}\text { resolution } \\
\text { of choroidal } \\
\text { lesion }\end{array}$ & $20 / 40$ & $\begin{array}{l}4 \\
\text { months }\end{array}$ \\
\hline $\begin{array}{l}\text { Daniels et al. } \\
{[8], 2010}\end{array}$ & $43 / \mathrm{M}$ & $\begin{array}{l}\text { NSCLC - } \\
\text { adenocarcinoma }\end{array}$ & $\mathrm{HM}$ & $\begin{array}{l}\text { yes; } \\
\text { bone, } \\
\text { brain }\end{array}$ & NS & $\begin{array}{l}\text { yes; } \\
\text { carboplatin } \\
\text { + paclitaxel }\end{array}$ & erlotinib & no & $\begin{array}{l}\text { resolution } \\
\text { of choroidal } \\
\text { lesion }\end{array}$ & $20 / 25$ & $\begin{array}{l}3 \\
\text { years }\end{array}$ \\
\hline $\begin{array}{l}\text { Inoue et al. } \\
{[14], 2010}\end{array}$ & $68 / \mathrm{F}$ & $\begin{array}{l}\text { NSCLC - } \\
\text { adenocarcinoma }\end{array}$ & $20 / 200$ & NS & NS & no & gefitinib & no & $\begin{array}{l}\text { resolution } \\
\text { of choroidal } \\
\text { lesion, subretinal } \\
\text { fluid reduced }\end{array}$ & $20 / 100$ & $\begin{array}{l}3 \\
\text { months }\end{array}$ \\
\hline $\begin{array}{l}\text { Shimomura } \\
\text { et al. [15], } \\
2013\end{array}$ & $53 / \mathrm{F}$ & $\begin{array}{l}\text { NSCLC - } \\
\text { adenocarcinoma }\end{array}$ & $20 / 200$ & $\begin{array}{l}\text { yes; } \\
\text { bones, } \\
\text { malignant } \\
\text { pleural } \\
\text { effusion }\end{array}$ & $\begin{array}{l}\text { exon } 19 \\
\text { deletion } \\
\text { mutation } \\
\text { (delE746- } \\
\text { A750) }\end{array}$ & no & gefitinib & no & $\begin{array}{l}\text { resolution } \\
\text { of choroidal } \\
\text { lesion, subretinal } \\
\text { fluid reduced }\end{array}$ & $20 / 100$ & $\begin{array}{l}5 \\
\text { months }\end{array}$ \\
\hline $\begin{array}{l}\text { Chen et al. } \\
\text { [7], } 2011\end{array}$ & $68 / \mathrm{F}$ & $\begin{array}{l}\text { NSCLC - } \\
\text { papillary } \\
\text { carcinoma }\end{array}$ & $20 / 60$ & $\begin{array}{l}\text { yes; } \\
\text { thyroid, } \\
\text { lung, } \\
\text { bones }\end{array}$ & $\begin{array}{l}\text { exon } 21 \\
\text { mutation } \\
\text { (L861Q) }\end{array}$ & no & erlotinib & no & $\begin{array}{l}\text { initial } \\
\text { improvement } \\
\text { followed by } \\
\text { worsening }\end{array}$ & $20 / 25^{\mathrm{b}}$ & $\begin{array}{l}7 \\
\text { months }\end{array}$ \\
\hline $\begin{array}{l}\text { Lai et al. } \\
{[16], 2012}\end{array}$ & $73 / \mathrm{M}$ & $\begin{array}{l}\text { NSCLC - } \\
\text { adenocarcinoma }\end{array}$ & $20 / 200$ & $\begin{array}{l}\text { yes; } \\
\text { sites NS }\end{array}$ & NS & $\begin{array}{l}\text { yes; } \\
\text { vinorelbine } \\
\text { + cisplatin }\end{array}$ & erlotinib & $\begin{array}{l}\text { intravitreal } \\
\text { bevacizumab }\end{array}$ & worsened ${ }^{c}$ & $10 / 200$ & $\begin{array}{l}2 \\
\text { months }\end{array}$ \\
\hline $\begin{array}{l}\text { Fujiu et al. } \\
{[17], 2012^{\mathrm{d}}}\end{array}$ & $49 / \mathrm{M}$ & $\begin{array}{l}\text { NSCLC - } \\
\text { adenocarcinoma }\end{array}$ & $20 / 200$ & $\mathrm{NS}^{\mathrm{d}}$ & exon 19 & $\mathrm{NS}^{\mathrm{d}}$ & erlotinib & no & $\begin{array}{l}\text { resolution } \\
\text { of choroidal } \\
\text { lesion }\end{array}$ & $20 / 18$ & $\begin{array}{l}4 \\
\text { days }^{d}\end{array}$ \\
\hline $\begin{array}{l}\text { Ye et al. [5], } \\
2014\end{array}$ & $48 / \mathrm{F}$ & $\begin{array}{l}\text { NSCLC - } \\
\text { subtype NS }\end{array}$ & $20 / 100$ & $\begin{array}{l}\text { yes; } \\
\text { bone, } \\
\text { brain }\end{array}$ & NS & no & erlotinib & no & $\begin{array}{l}\text { resolution } \\
\text { of choroidal } \\
\text { lesion }\end{array}$ & $20 / 25$ & $\begin{array}{l}5 \\
\text { months }\end{array}$ \\
\hline Current case & $78 / \mathrm{M}$ & $\begin{array}{l}\text { NSCLC - } \\
\text { adenocarcinoma }\end{array}$ & $20 / 60$ & $\begin{array}{l}\text { yes; } \\
\text { bones }\end{array}$ & wild-type & no & erlotinib & no & $\begin{array}{l}\text { resolution } \\
\text { of choroidal } \\
\text { lesion }\end{array}$ & $20 / 30$ & $\begin{array}{l}1 \\
\text { year }\end{array}$ \\
\hline
\end{tabular}

Singh et al. [25] in their series reported two cases of lung cancer with choroidal metastases that received EGFR-TKIs. EGFR mutation status was not specified for either patient. One patient received oral gefitinib as second-line chemotherapy and the other oral erlotinib as third-line palliative medication. None of the cases had an ophthalmologic follow-up documenting the disease after initiation of TKI, hence they were not included in this table. FU = Followup; $\mathrm{HM}=$ hand movement; NS = not specified.

${ }^{a}$ Choroidal lesions responded to gefitinib, but the patient developed brain metastases while on gefitinib, hence it was discontinued. ${ }^{\mathrm{b}}$ After 7 months, reaccumulation of subretinal fluid was noted and vision dropped to 20/80, which prompted a change of drug to docetaxel. ${ }^{\mathrm{c}}$ The choroidal lesions worsened while the patient was on oral erlotinib, following which they showed improvement on treatment with intravitreal bevacizumab, remaining stable for 4 months. ${ }^{\mathrm{d}}$ The details of this case are from the English abstract (the original article is in Japanese).

tion, and metastasis, thereby causing minimal collateral damage [7]. Therefore, in advanced cases of NSCLCs with systemic metastases, where chemotherapy may worsen the quality of 'life near death', therapy with oral TKIs may be considered in cases of choroidal metastases from NSCLCs [24].
We believe our case demonstrates that newer drugs like erlotinib can be useful in the treatment of choroidal metastases in cases of NSCLC that overexpress EGFR. The use of TKIs to treat choroidal metastases from the lung may be considered even in the absence of any detectable mutations. 


\section{Disclosure Statement}

The authors certify that they have no affiliations with or involvement in any organization or entity with any financial interest (such as honoraria, educational grants, participation in speakers' bureaus, membership, employment, consultancies, stock ownership, or other equity interest, and expert testimony or patent licensing arrangements), or nonfinancial interest (such as personal or professional relationships, affiliations, knowledge or beliefs), in the subject matter or materials discussed in this paper.

\section{Statement of Ethics}

This submission complies with the guidelines for human studies and animal welfare regulations. This paper does not involve any experimental drug that does not have FDA approval. The treatment of the subject described in this paper was carried out after obtaining informed consent. No animal experiments were carried out with regards to this submission.

\section{References}

1 Noronha V, Dikshit R, Raut N, Joshi A, Pramesh CS, George K, Agarwal JP, Munshi A, Prabhash K: Epidemiology of lung cancer in India: focus on the differences between non-smokers and smokers: a single-centre experience. Indian J Cancer 2012;49:74-81.

2 Molina JR, Yang P, Cassivi SD, Schild SE, Adjei AA: Non-small cell lung cancer: epidemiology, risk factors, treatment, and survivorship. Mayo Clin Proc 2008;83:584-594.

3 Nair AG, Asnani HT, Mehta VC, Mehta SV, Pathak RS: Metastatic adenocarcinoma of the cervix presenting as a choroidal mass: a case report and review of literature of cervical metastases to the eye. Indian J Ophthalmol 2015; 63:674-678.

4 Ferry AP, Font RL: Carcinoma metastatic to eye and orbit. A clinicopathologic study of 227 cases. Arch Ophthalmol 1974;92:276286.

5 Ye X, Kaliki S, Shields CL: Rapid regression of choroidal metastasis from lung cancer using erlotinib (Tarceva). Oman J Ophthalmol 2014;7:75-77.

6 Carpenter G: Receptors for epidermal growth factor and other polypeptide mitogens. Annu Rev Biochem 1987;56:881-914.

7 Chen CJ, McCoy AN, Brahmer J, Handa JT: Emerging treatments for choroidal metastases. Surv Ophthalmol 2011;56:511-521.

8 Daniels AB, Miller ML, Kotecha A, Abramson DH: Uveal metastasis from nonsmall cell lung carcinoma with dramatic response to erlotinib. Retin Cases Brief Rep 2010;4:390-393.

9 Jerram AH, Smith PF, Darlington CL: A doseresponse analysis of the behavioral effects of $(+)$ MK-801 in guinea pig: comparison with CPP. Pharmacol Biochem Behav 1996;53:799-807.

10 Desai C, Mehta A, Mishra D: Usage patterns of biomarkers in non-small-cell lung cancer patients in India: findings from a systematic review and survey. Lung India 2014;31:249259.

11 Bhatt AD, Pai R, Rebekah G, Nehru GA, Dhananjayan S, Samuel A, Singh A, Joel A, Korula A, Chacko RT: Clinicopathologic features of non-small cell lung cancer in India and correlation with epidermal growth factor receptor mutational status. Indian J Cancer 2013;50:94-101.
12 Ovcaricek T, Cufer T, Kern I, Sodja E, Sadikov A: Efficacy of tyrosine kinase inhibitors in routine clinical practice: epidermal growth factor mutations and their implications. J Cancer Res Ther 2013;9:261-266.

13 Kim SW, Kim MJ, Huh K, Oh J: Complete regression of choroidal metastasis secondary to non-small-cell lung cancer with intravitreal bevacizumab and oral erlotinib combination therapy. Ophthalmologica 2009;223: 411-413.

14 Inoue M, Watanabe Y, Yamane S, Kobayashi S, Arakawa A, Tsukahara T, Kaneko T, Kadonosono K: Choroidal metastasis with adenocarcinoma of the lung treated with gefitinib. Eur J Ophthalmol 2010;20:963-965.

15 Shimomura I, Tada Y, Miura G, Suzuki T, Matsumura T, Tsushima K, Terada J, Kurimoto R, Sakaida E, Sekine I, Takiguchi Y, Yamamoto S, Tatsumi K: Choroidal metastasis of non-small cell lung cancer that responded to gefitinib. Case Rep Ophthalmol Med 2013; 2013:213124.

16 Lai CL, Fan KS, Lee YH, Chen HC, Fan WH: Intravitreal administration of bevacizumab in the treatment of choroidal metastasis in a patient with erlotinib-failed pulmonary adenocarcinoma. Lung Cancer 2012;76:496-498.

17 Fujiu K, Kobayashi N, Miyamoto H, Suzuki $\mathrm{H}$ : A case of choroidal metastasis of lung cancer successfully treated with erlotinib. Gan To Kagaku Ryoho 2012;39:269-271.

18 Jazieh AR, Al Sudairy R, Abu-Shraie N, Al Suwairi W, Ferwana M, Murad MH: Erlotinib in wild type epidermal growth factor receptor non-small cell lung cancer: a systematic review. Ann Thorac Med 2013;8:204-208.

19 Kim ES, Hirsh V, Mok T, Socinski MA, Gervais R, Wu YL, Li LY, Watkins CL, Sellers MV, Lowe ES, Sun Y, Liao ML, Osterlind K, Reck M, Armour AA, Shepherd FA, Lippman SM, Douillard JY: Gefitinib versus docetaxel in previously treated non-small-cell lung cancer (INTEREST): a randomised phase III trial. Lancet 2008;372:1809-1818.

20 Maruyama R, Nishiwaki Y, Tamura T, Yamamoto N, Tsuboi M, Nakagawa K, Shinkai T, Negoro S, Imamura F, Eguchi K, Takeda K, Inoue $\mathrm{A}$, Tomii $\mathrm{K}$, Harada $\mathrm{M}$, Masuda N, Jiang H, Itoh Y, Ichinose Y, Saijo N, Fukuoka
M: Phase III study, V-15-32, of gefitinib versus docetaxel in previously treated Japanese patients with non-small-cell lung cancer. J Clin Oncol 2008;26:4244-4252.

21 Hirsh V: Second-line erlotinib in an EGFR mutation-negative patient with non-smallcell lung cancer. Curr Oncol 2012;19:21-22.

22 Rosell R, Carcereny E, Gervais R, Vergnenegre A, Massuti B, Felip E, Palmero R, GarciaGomez R, Pallares C, Sanchez JM, Porta R, Cobo M, Garrido P, Longo F, Moran T, Insa A, De Marinis F, Corre R, Bover I, Illiano A, Dansin E, de Castro J, Milella M, Reguart N, Altavilla G, Jimenez U, Provencio M, Moreno MA, Terrasa J, Muñoz-Langa J, Valdivia J, Isla D, Domine M, Molinier O, Mazieres J, Baize N, Garcia-Campelo R, Robinet G, RodriguezAbreu D, Lopez-Vivanco G, Gebbia V, Ferrera-Delgado L, Bombaron P, Bernabe R, Bearz A, Artal A, Cortesi E, Rolfo C, Sanchez-Ronco M, Drozdowskyj A, Queralt C, de Aguirre I, Ramirez JL, Sanchez JJ, Molina MA, Taron M, Paz-Ares L; Spanish Lung Cancer Group in collaboration with Groupe Français de Pneumo-Cancérologie and Associazione Italiana Oncologia Toracica: Erlotinib versus standard chemotherapy as first-line treatment for European patients with advanced EGFR mutation-positive non-small-cell lung cancer (EURTAC): a multicentre, open-label, randomised phase 3 trial. Lancet Oncol 2012;13: 239-246.

23 Zhang WQ, Li T, Li H: Efficacy of EGFR tyrosine kinase inhibitors in non-small-cell lung cancer patients with/without EGFR-mutation: evidence based on recent phase III randomized trials. Med Sci Monit 2014;20:26662676.

24 Prigerson HG, Bao Y, Shah MA, Paulk ME, LeBlanc TW, Schneider BJ, Garrido MM, Reid MC, Berlin DA, Adelson KB, Neugut AI, Maciejewski PK: Chemotherapy use, performance status, and quality of life at the end of life. JAMA Oncol 2015;1:778-784.

25 Singh N, Kulkarni P, Aggarwal AN, Rai Mittal B, Gupta N, Behera D, Gupta A: Choroidal metastasis as a presenting manifestation of lung cancer: a report of 3 cases and systematic review of the literature. Medicine (Baltimore) 2012;91:179-194. 